\title{
USE OF TASK-BASED APPROACH IN TEACHING VOCABULARY TO BUSINESS ENGLISH LEARNERS AT UNIVERSITY
}

\author{
Nellia Nychkalo ${ }^{1}$, Wang Jinba ${ }^{2}$, Larysa Lukianova ${ }^{3}$, \\ Nataliia Paziura $^{4}$ (Corresponding author), Nataliia Muranova ${ }^{5}$ \\ ${ }^{1,3}$ National Academy of Pedagogical Sciences of Ukraine, Kyiv, Ukraine \\ ${ }^{2}$ Yuncheng University, Shanxi, China \\ ${ }^{4,5}$ National Aviation University, Kyiv, Ukraine \\ npazyura@ukr.net
}

\begin{abstract}
The purpose of this study is to identify the effectiveness of the task-based approach to teaching business vocabulary to master's degree students while studying business English. The discipline of business English aims to develop students' ability to analyse and solve problems of the business environment, improve their foreign language competence on the basis of acquired business vocabulary. The authors used the task-based approach in teaching business vocabulary which was aimed at encouraging students to social contacts, discussions, use of the necessary lexical units in situations close to real business life. The participants of the study were 34 students who studied for a master's degree at the National Aviation University (Kyiv, Ukraine) majoring in aviation, rocket and space technology. The study of the course required 34 academic hours. According to the methodology of the experiment, the two groups of students (control and experimental ones) had the same learning materials during the course, but the teaching methods were different. In the control group, we used traditional vocabulary learning methods which implied the presentation of the new vocabulary by the teacher, practice exercises which made learners more familiar with the lexical units and the use of the new vocabulary by students in context. In the experimental group, task-based learning method was used which required students to work on solving real business problems with special attention to the development of teamwork skills and communication skills based on the students' experience of work in business and communication with colleagues from other countries. Specially designed tasks were used to intensify the process of learning business vocabulary. The study showed significant positive dynamics in the acquisition of business vocabulary by students of the experimental group. The results of the test confirmed that task-based approach to vocabulary learning allows students to learn the necessary business vocabulary on a particular topic more easily and quickly It has been concluded that the task-based approach is not only efficient in vocabulary learning, but also increases the students' confidence in their professional and communicative competence.
\end{abstract}

Keywords: task-based approach; business English vocabulary; communicative competence; group work; master's degree students.

\section{Introduction}

Learning a foreign language is a difficult task which in the past was often associated with memorising words and phrases, thoughtless repetition of the material learned in class and complete inability to speak outside the classroom. With time, the use of teacher-centred methods that focus mainly on learning content through memorisation and translation has gradually shifted to more communicative methods and approaches, one of which is the task-based method.

Prabhu (1987) first mentioned task-based learning (TBL) in 1982 as a method of the learner-centred approach. Richards and Schmidt (2010) note that the learner-centred approach places the student at the centre of all stages of language learning, including planning, learning and assessment. Emphasising the importance of the TBL, Ellis (2003) claims that it encourages students to socialise, work in groups, and as also helps to solve social problems. While interacting with each other in simulated situations to perform the task students help each other in learning, monitor the achievements of others, offer their options for solving a problem, communicate with the full use of their linguistic knowledge and previous experience. As argued by Prabhu (1987), a language task is an activity that requires a student to achieve a result by processing and reflecting on certain information. It allows the teacher to control and influence this process. The teacher also prepares students to participation in communicative tasks, assures that they spend most of the time on speaking and discussing, helps them learn the language through meaningful communication. Bhandari (2020) consideres task-based language teaching to be one of the widely discussed teaching approaches at present with its characteristics and advantages. He insists that though English language teachers hold positive attitudes on task-based language teaching as a current EFL approach, they are not well aware of the methods of using this approach in their classrooms.

(C) Nellia Nychkalo, Wang Jinba, Larysa Lukianova, Nataliia Paziura, Nataliia Muranova. 2020. Published by Igor Sikorsky Kyiv Polytechnic Institute. This is an Open Access article distributed under the terms of the licence CC BY 4.0 
Nunan (1989) defines communicative tasks as homework that encourages students to interact using a foreign language with a focus on meaning rather than form. The teacher's aim is to choose tasks that help to ensure the students' motivation and involvement in the learning process. Tasks are key components of taskbased language learning. As stated by Ellis (2003) language tasks promote the development of students' receptive or reproductive speaking and writing skills along with the cognitive process.

Language tasks, if properly used, enhance the communicative abilities of students. Gong and Luo (2003) insist that the main idea of the problem-based approach is to promote different types of tasks that people perform in society. That is, the best way to learn a language is to perform a variety of language tasks in which the student actively uses the language in communication, so the process of language acquisition occurs naturally. Language tasks are mostly targeted and are developed with consideration of the life experience of students. Emphasising the advantages of language tasks, Lambert (2019) insists that task-based language learning is an unplanned process that addresses the needs of students when they are focused on achieving communicative results.

A range of studies focuse on the use of task-based approach in teaching professional and language competences to students of different specialities - mechanical engineering, aviation, translation and others (Li, 2013; Alenezi, 2020; Bystrova et al., 2019; Lytovchenko et al., 2018). Scholars have studied the use of task-based approach in the development of various language skills - listening, speaking, reading, writing, grammar and others. For example, Kafipour, Mahmoudi and Khojasteh (2018) find the task-based approach extremely effective in the development of students' analytical writing skills. Albino (2017) draws attention to a significant body of empirical research which confirms the effectiveness of the task-based approach in the improvement of language fluency and grammatical accuracy. The possibilities of using tasks for teaching grammar were also explored by Lytovchenko et al. (2020) who present successful examples of such uses and emphasise that task-based learning creates a communicative context which provides possibilities to focus the students' attention on grammatical forms.

Sarani and Sahebi (2012) focus on the study of vocabulary in English for Specific Purposes (ESP) using the task-based method and note that it has shown its effectiveness in teaching technical vocabulary compared to traditional teaching methods. Since vocabulary is a key component of language proficiency that provides the basis for how a student will speak, listen, read, and write (Richards \& Renandya, 2002), our research is devoted to the development of vocabulary skills, particularly in a course of business English at university, with the use of the task-based approach.

\section{Aim and hypothesis}

In our study, we hypothesised that, compared to traditional learning methods, the task-based method would be more effective in teaching business vocabulary and help students to prepare for employment in business environment after graduation. The aims of our study were: 1) to compare the efficiency of traditional methods and task-based learning method in teaching business English vocabulary at university; 2) to find out students 'attitudes to task-based learning in order to address students' needs more fully.

\section{Methods}

Research Design

To achieve the aims we chose a mixed research design implying the use of quantitative and qualitative research methods. A quantitative method was used to process the test results of students in the groups which used the traditional learning method and TBL method before and after the Business English course. Qualitative method was used to explore the students' answers to open-ended questions in the questionnaire.

\section{Participants}

The study involved 34 master's degree students of the National Aviation University (Kyiv, Ukraine) majoring in Aviation, Rocket and Space Engineering who took a course of business English in the autumnwinter semester of 2019. They participated in the experiment voluntarily and could stop participating at any time. The study of the course covered 34 academic hours ( 2 academic hours per week). Since the admission to the master's degree programme was based on the results of national exams in English, the students' language proficiency level was approximately the same - B2 according to the Common European Framework of Reference (CEFR). The students were divided into two groups (each containing 17 participants) - control and experimental ones. The control group was taught business English with the use of traditional methods, the experimental group - with the use of the task-based method. We found it appropriate to involve master's degree students because most of them had already had the experience of work in business and therefore were able to use it to perform the proposed tasks. 


\section{Materials and Procedure}

During the semester, both groups studied the following topics within the course: "Company Structure", "Employment and Career Development", "Working in a Multinational Company". The same learning materials were used in both groups.

The group taught with the use of traditional methods received the usual instructions which included explaining new business terms and new concepts, completing oral and written assignments, writing essays using one's own experience of job interviews, work in companies, communication with colleagues from other countries.

In the experimental group, we used the task-based approach. Students performed most of the tasks in groups. The tasks were as close as possible to real situations of the business environment, students worked on solving real business problems. Special attention was paid to the development of teamwork skills and communication skills. All the tasks which were offered to students within the course can be divided into three stages: preparatory, executive, final ones. At the preparatory stage, new vocabulary was introduced to students, stimulating their imagination, motivating them to associate new knowledge with previous life experience. In the executive stage, the tasks stimulated students to transform their understanding of the external characteristics of the phenomenon into internal cognitive connections. At the final stage, students performed communicative tasks which involved simulating business situations in an English-speaking environment, filling the information gap between interlocutors, solving practical problems. When performing the tasks at the final stage, we tried to give students maximum autonomy and support their creativity.

In Table 1, we give an example of the implementation of three stages of performing tasks when studying the topic "Company structure" in the experimental group (Tullis \& Trappe, 2007).

Table 1. Company structure

\begin{tabular}{|l|l|}
\hline Stage & \multicolumn{1}{c|}{ Procedure } \\
\hline Preparatory & $\begin{array}{l}\text { The teacher suggests studying the organisation chart and thinking about shareholders' } \\
\text { functions. } \\
\text { Then the teacher explains the place occupied by the board of directors in the company } \\
\text { hierarchy. The students are informed about important departments of the company and the } \\
\text { functions of their workers. }\end{array}$ \\
\hline Executive & $\begin{array}{l}\text { The teacher asks students to match products to the departments which they come from. Then } \\
\text { they choose the department where they would like to work taking into consideration their own } \\
\text { skills, abilities and inclinations. }\end{array}$ \\
\hline Final & $\begin{array}{l}\text { Students are asked to study the background of Auric Bank (Italia) which lost money because } \\
\text { of investing in unprofitable areas of business and needs to reduce costs to boost its profits and } \\
\text { share price. } \\
\text { Students are offered to play the role of the director of AB. They are asked to prepare for a } \\
\text { meeting with shareholders to discuss possible ways of solving the problem. The task is to } \\
\text { discuss the advantages and disadvantages of every option. The students should be ready to } \\
\text { make a contribution to group work, take a turn in the discussion, persuade the others. }\end{array}$ \\
\hline
\end{tabular}

To identify the effectiveness of the task-based approach in the study of business vocabulary, students of both groups were offered a pre-test at the beginning of the course, and a post-test after its completion. The tests were designed by Paziura (2018). In both groups, they were identical and consisted of tasks aimed at assessment of business vocabulary acquisition by students before and after the experimental learning. The tasks were of different types: multiple-choice, matching, transformation, cloze text, gap-filling.

In the experimental group, we also used a questionnaire which contained open-ended questions requiring the students to elaborate on their attitudes to the task-based learning: 1. Did you like the tasks you performed during Business English course? Explain why/why not? 2. Do you think the skills acquired in classroom will be useful at the workplace? If so, specify what useful skills you have acquired. 3 . What difficulties did you face, if any, in learning business vocabulary while working on the tasks?

\section{Results}

The results of pre-testing revealed no significant differences in the levels of communication skills in both groups (See Tables 2 and 3). To evaluate the results, we used the ABCDEF scale which implied 95$100 \%, 94-85 \%, 84-75 \%, 74-65 \%, 64-60 \%, 59-0 \%$ of correct answers, respectively. Prior to the beginning of the experimental study, both groups had approximately the same number of students who received grades A (4 (23.6\%) and $3(17.6 \%)$ students, respectively), B (5 (29.4\%) and 4 (23.6\%) students, respectively), C (4 (23.6\%) students in each group), D (2 (11.7\%) and 3 (17.6\%) students, respectively), E (2 (11.7\%) and 3 (17.6\%) students, respectively). After the course, according to the test results, positive dynamics was 
observed in both groups. However, the percentage of students who received high grades $(A, B, C)$ in the experimental group increased significantly (almost twice) compared to the group that used traditional teaching methods (by $11.9 \%$ vs $5.9 \%, 11.6 \%$ vs $5.8 \%, 5.9 \%$ vs $11.6 \%$, respectively). Also, the percentage of students who received low grades, $\mathrm{D}$ and $\mathrm{E}$, decreased more significantly in the experimental group than in the control group (by $17.6 \%$ vs $5.9 \%, 17.6 \%$ vs $11.7 \%$, respectively).

Table 2. Test results of students in the group which used traditional methods before and after the Business English course

\begin{tabular}{|c|c|c|c|c|c|}
\hline \multirow{2}{*}{ Grades } & \multicolumn{2}{|c|}{ Before the course } & \multicolumn{2}{c|}{ After the course } & $\begin{array}{c}\text { Total difference } \\
\%\end{array}$ \\
\cline { 2 - 6 } & $\begin{array}{c}\text { Number of } \\
\text { students }\end{array}$ & $\%$ & $\begin{array}{c}\text { Number of } \\
\text { students }\end{array}$ & $\%$ & +5.9 \\
\hline A & 4 & 23.6 & 5 & 29.5 & +5.8 \\
\hline B & 5 & 29.4 & 6 & 35.2 & +5.9 \\
\hline C & 4 & 23.6 & 5 & 29.5 & -5.9 \\
\hline E & 2 & 11.7 & 1 & 5.8 & -11.7 \\
\hline
\end{tabular}

Table 3. Test results of students in the group which used TBL method before and after the Business English course

\begin{tabular}{|c|c|c|c|c|c|}
\hline \multirow{2}{*}{ Grades } & \multicolumn{2}{|c|}{ Before the course } & \multicolumn{2}{c|}{ After the course } & $\begin{array}{c}\text { Total difference } \\
\%\end{array}$ \\
\cline { 2 - 6 } & $\begin{array}{c}\text { Number of } \\
\text { students }\end{array}$ & $\%$ & $\begin{array}{c}\text { Number of } \\
\text { students }\end{array}$ & $\%$ & +11.9 \\
\hline A & 3 & 17.6 & 5 & 29.5 & +11.6 \\
\hline C & 4 & 23.6 & 6 & 35.2 & +11.6 \\
D & 4 & 23.6 & 6 & 0 & -17.6 \\
\hline E & 3 & 17.6 & - & 0 & -17.6 \\
\hline
\end{tabular}

We analysed students' answers to the questions in the questionnaire. Their analysis showed that almost all students (16 students - 94.1\%) liked task-based learning of business vocabulary. Among the most common answers were: "the tasks help to understand the difference between words that are similar in meaning"; "after completing these tasks I can remember new terms easily, without boring mechanical memorisation"; "while working on tasks we talked a lot but didn't write". Only one student answered that he could remember words better when he learnt them by heart and even wrote them down several times.

When asked about the usefulness of the acquired skills in the future workplace, 15 students $(88.2 \%)$ were sure that the skills acquired by them during the study of the course would be useful. Only 2 students $(11.8 \%)$ believed that their professional responsibilities would not include oral communication in English, but only the translation of contracts and similar business documentation. All 17 students (100\%) said that it became much easier for them to communicate in English. They explained the main reasons for this by the fact that they knew how to start a conversation on an important topic, how to convince the interlocutor, how to present themselves in the best way. Even those students who almost never took part in the discussions before the course because they felt insecure due to insufficient vocabulary and difficulty using "the right words in the right situation" began to take an active part in the discussions. The students described this course as extremely important, one that introduces them to the potential problems of the future workplace, and provides examples of solutions to these problems.

When asked about the difficulties, 15 students $(88.2 \%)$ answered that the tasks they performed in class were interesting and not difficult for them. Certain difficulties arose in tasks where it was necessary to choose between almost identical words without a dictionary. For 2 students $(11.7 \%)$ the most difficult tasks were those in which they were asked to present their own vision of solving a real business problem of the company, as they did not yet have any experience of work in a company.

\section{Discussion}

Based on the results of our research, we can conclude that the task-based approach to vocabulary learning allows students to learn the necessary business vocabulary on a particular topic more easily and quickly. We conducted a study in which we tried to use the task-based approach to teaching business vocabulary of three modules. We selected two groups of students - a group that used a traditional approach 
to learning and a TBL group. Comparison of the results of the post-test showed that the students of the experimental group had better results than the students of the traditional learning group.

As we can see from the positive feedback of students of the experimental group, they liked the taskbased method in learning business vocabulary, as it helped not only to enrich the vocabulary but also to enhance teamwork skills, overcome their uncertainty in communication, develop individual language learning strategies. It was important that the focus was on the spontaneous, creative use of language, rather than on the absolute accuracy of the use of lexical units. At the same time, task-based learning allows students to understand that language, among other things, is a tool for solving real problems of everyday life. While working on tasks students learn to ask questions, interact in groups. They also have an opportunity to observe different approaches to solving problems and making decisions that other students offer. Performing real business tasks students learn how to best present themself to the future employer, communicate and cooperate with colleagues, navigate in the company structure as well as a gain deeper understanding of the responsibilities of employees and management in a company. Task-based learning allows students to move away from the mechanical memorising of new words and provides them with opportunities to focus on communication and interaction using vocabulary which is appropriate in a particular situation.

As shown by the results of our research, task-based vocabulary learning is a powerful tool for improvement of students' communication skills and their ability to use the acquired knowledge. It prepares students to be both listeners and team players and bridges the gap between theory and practice. We fully share the opinion that tasks based on life situations from the business environment help students to be more confident and prepared to starting a business (Grosse, 1988). The results of our study are consistent with those obtained by Guiyu and Yi (2017) and confirm that acquaintance with business environment and preparation for future job motivates students to analyse and solve problems, encourages them to acquire new knowledge and improve their skills (p. 28).

At the same time, we found some difficulties due to the fact that sometimes students lacked language means to express themselves and sometimes the real business tasks, being professionally specific, were too difficult for them since they had little or no job experience in business. We agree with Chen and Shi (2015) that not only students but also teachers sometimes have difficulties in TBL, particularly in choosing appropriate tasks, using professional business vocabulary. TBL requires teachers not only to realistically assess students' language proficiency and business knowledge but also to assign tasks which meet students' individual needs and support their interest. During the tasks, the teacher must have some control over the discussion of the problem in student groups and ensure gradual progress in the discussions. At the end of the discussion, the teacher should comment on the results and make a brief conclusion, so that students have a clear idea of their achievements.

Our research has also revealed that the teacher may sometimes overestimate the students' language level, speak too quickly, using unfamiliar terms, which leads to misunderstanding of the basic concepts by students. We can see the need to establish proper communication between teacher and students in order to eliminate the difficulties and thus fully support Esteban and Pérez Cañado (2004) in that it is important to support students' self-confidence. Teachers should also help students understand that the problem-based learning is a method based on critical thinking.

Our research was limited to only one group of students enrolled in the master's programme of the National Aviation University (Ukraine). A study involving a bigger number of students in other national contexts could provide more convincing results to confirm or deny the efficiency of the task-based vocabulary learning.

\section{Conclusions}

The results of our study allow us to make the conclusion about the effectiveness of the task-based approach to teaching business English vocabulary. The defining feature of this approach that ensures the effectiveness of learning is the reproduction of real situations in business that urges students to communicate with each other using targeted vocabulary to solve real business problems. Besides the positive role in the effective development of foreign language competence the task-based approach also increases the students' desire to communicate in English.

\section{References:}

Alenezi, A.M. (2020). Task-based Approach in Teaching Translation: A Case Study in Jouf University. Higher Education Studies, 10(2), 189-196. https://doi.org/10.5539/hes.v10n2p189

Albino, G. (2017). Improving speaking fluency in a task-based language teaching approach: The case of EFL learners at PUNIVCazenga. SAGE Open, 7(2), 1-11. https://doi.org/10.1177/2158244017691077 
Bhandari, L. P. (2020). Task-Based Language Teaching: A Current EFL Approach, Advances in Language and Literary Studies, 11 (1), 1-5. https://dx.doi.org/10.7575/aiac.alls.v.11n.1p.1

Bystrova, B., Nemliy, L., Paziura, N. \& Vasiukovych, O. (2019). Problem-based ESP methods for teaching future air traffic controllers to conduct radio exchange in non-routine situations. Advanced Education, 6(12), 74-79. https://doi.org/10.20535/2410-8286.155041

Chen, M. \& Shi, X. (2015). The Research of Multidimensional Interactive Teaching for College English. US-China Foreign Language, 13(12), 864-868. https://doi.org/10.17265/1539-8080/2015.12.003

Ellis, R. (2003). Task-based language learning and teaching. Oxford University Press, Oxford.

Esteban, A. A. \& Pérez Cañado, M. L. (2004). Making the case method work in teaching Business English: a case study. English for Specific Purposes, 23(2), 137- 161. https://doi.org/10.1016/s0889-4906(03)00016-4

Grosse, Ch. U. (1988). The case study approach to teaching business English. English for Specific Purposes, 7(2), 131-136. https://doi.org/10.1016/0889-4906(88)90031-2

Guiyu, D. \& Yi, C. (2017). Application of Case-Task Based Approach in Business English Teaching - A Case Study of the Marketing Course in SEIB of GDUFS. Higher Education Studies, 7(1), 23-29 https://doi.org/10.5539/hes.v7n1p23

Gong, Y. F., \& Luo, S. Q. (2003). Task-Based Language Teaching. Beijing: People's Education Press.

Kafipour, R., Mahmoudi, E. \& Khojasteh, L. (2018). The effect of task-based language teaching on analytic writing in EFL classrooms, Cogent Education, 5(1), 1-16. https://doi.org/10.1080/2331186x.2018.1496627

Lambert, C. (2019). Referent similarity and normal syntax in task-based language teaching. Springer. https://doi.org/10.1007/978981-13-3089-6

Li, D. (2013). Teaching Business Translation. The Interpreter and Translator Trainer, 7(1), 1-26. https://doi.org/10.1080/13556509.2013.10798841

Lytovchenko, I., Lavrysh, Y., Lukianenko, V., \& Ogienko, O. (2020). How to teach grammar to adult ESP learners at technical university more communicatively: task-based approach. Multidisciplinary Journal for Education, Social and Technological Sciences, 7(1), 54-71. https://doi.org/10.4995/muse.2020.12419

Lytovchenko, I. Ogienko, O., Sbruieva, A., Sotska, H. (2018). Teaching English for specific purposes to adult learners at university: methods that work. Advanced education, 10, 69 -75. https://doi.org/10.20535/2410-8286.149741

Nunan, D. (1989). Designing tasks for the communicative classroom. Cambridge: Cambridge University Press.

Paziura, N. (2018). Aviation Business English. Kyiv: NAU.

Prabhu, N. S. (1987). Second language pedagogy. Oxford: Oxford University Press.

Richards, J. C., \& Schmidt, R. (2010). Longman dictionary of language teaching and applied linguistics (4th Ed.). Longman.

Richards, J. C., \& Renandya, W. A. (2002). Methodology in language teaching. Cambridge: Cambridge university press. http://dx.doi.org/10.1017/CBO9780511667190

Sarani, A. \& Sahebi, F.L. (2012). The Impact of Task-based Approach on Vocabulary Learning in ESP Courses. English Language Teaching, 5(10), 118-128. https://doi.org/10.5539/elt.v5n10p118

Tullis, G. \& Trappe, T. (2007). Insight into Business English. UK: Pearson Longman. 